\title{
EXTRAHEPATIC MANIFESTATIONS IN PATIENTS WITH CHRONIC HEPATITIS C
}

\author{
Olga P. Dudanova ${ }^{1}$, Marina E. Shubina ${ }^{1}$, Maria M. Pisareva ${ }^{2}$, Mikhail P. Grudinin $^{2}$ \\ ${ }^{1}$ Petrozavodsk State University, Petrozavodsk, Russia \\ ${ }^{2}$ Research Institute of Influenza of the Ministry of Health, Saint-Petersburg, Russia \\ O.P. Dudanova \\ 33 Lenin Avenue, Petrozavodsk, Russia 185910 \\ odudanova@gmail.com
}

\begin{abstract}
The aim of the study was to determine extrahepatic manifestations (EHM) of chronic hepatitis $\mathrm{C}(\mathrm{CHC})$ in patients with genotype 1 and $3 \mathrm{a}$ infections.

Materials and methods. We examined 83 patients with $\mathrm{CHC}: 42(50.6 \%)$ with genotype 1 , and $41(49.4 \%)$ with genotype $3 \mathrm{a} ; 49(59.0 \%)$ were males, $34(41.0 \%)$ were females; the mean \pm SD age of patients was $39.3 \pm 12.3$ (range: $17-72$ ) years. Chronic hepatitis was diagnosed in 75 $(90.4 \%)$ patients, and cirrhosis - in $8(9.6 \%)$. Clinical, laboratory, histological, biochemical and virological data (AbHCV, viral RNA) were obtained.

Results. EHM were observed in $27(32.5 \%)$ patients: in 18 (42.9\%) with genotype 1 infection, and in $9(21.9 \%)$ with genotype $3 \mathrm{a}$ infection. The following manifestations were diagnosed: arthralgia (14.5\%), purpura (8.4\%), glomerulonephritis $(6.0 \%)$, thyroiditis $(6.0 \%)$, type 2 diabetes mellitus (3.6\%), non-Hodgkin lymphoma (1.2\%), Raynoud's phenomenon (1.2\%), psoriasis $(1.2 \%)$, vitiligo $(1.2 \%)$. Cryoglobulinemia was detected in $9(10.8 \%)$ patients. On average, EHM were revealed 2 times more frequently in females $(25.3 \%)$ than in males $(7.2 \%)$.

Conclusion. Extrahepatic manifestations in CHC were observed in $32.5 \%$ of patients, more frequently in patients infected with genotype 1 virus and in females, than in patients with genotype $3 \mathrm{a}$ infection and males.
\end{abstract}

Keywords: extrahepatic manifestations, chronic hepatitis C, genotype 1, genotype 3a. 


\section{Background}

Chronic hepatitis $\mathrm{C}$ (CHC) is often accompanied by involvement of other organs and systems in pathological process with development of cutaneous vasculitis, arthritis, glomerulonephritis, thyroiditis, Sjogren's syndrome, cutaneous porphyria, neuropathy, lymphoproliferative and other disorders (Ali, 2005; Galossi, 2007; Krel, 2009; Băkova, 2013). Multisystem affection in chronic HCV (hepatitis $\mathrm{C}$ virus) infection is caused by many reasons: the ability of hepatitis $\mathrm{C}$ virus to replicate not only in the liver, but in other organs as well; the circulation of immune complexes in the blood; polyclonal activation of B-cells infected by the virus; mixed cryoglobulinemia; HCV mutations and emergence of crisscross immune reactions; peculiarities of immune reactivity of the host. Sometimes extrahepatic manifestations (EHM) of chronic HCV-infection are more severe and unfavorable than the liver lesion. The frequency, type, and clinical relevance of EHM in CHC can vary depending on the geographic region, prevalence of $\mathrm{CHC}$ in this region, duration of chronic $\mathrm{HCV}$-infection, adequacy of patient examination and other conditions.

The aim of our study was to determine forms and prevalence of extrahepatic manifestations in chronic hepatitis $\mathrm{C}$ patients carrying $\mathrm{HCV}$ of different subtypes.

\section{Materials and methods}

CHC patients admitted to the Petrozavodsk Railway Hospital during 2005-2013 were involved in research. HCV-infection was confirmed by the presence of anti-HCV antibodies using ELISA test-system ("Vector-Best", Novosibirsk, Russia) and by positive test for HCV-RNA using PCR test-system ("AmpliSens HCV”, Central Research Institute of Epidemiology, Moscow, Russia). The HCV genotypes were identified by "AmpliSens HCV genotype" test-system (Central Research Institute of Epidemiology, Moscow, Russia).

Liver biopsy was performed in $70(84.3 \%)$ patients; the grade of histological activity was estimated according to the Knodell system and the stage of fibrosis - according to the METAVIR.

Cryoglobulins were detected as described in (Kallemuchikkal, 1999), specifically: $10 \mathrm{ml}$ of venous blood were obtained from a patient in a warmed up to $37^{\circ} \mathrm{C}$ test-tube, after that serum was separated by centrifugation, the supernatant was incubated in a capillary in vertical position at $4^{\circ} \mathrm{C}$ for 7 days and then examined for cryoprecipitate.

Laboratory analyses, abdominal and thyroid gland ultrasonography, esophagogastroscopy were carried out routinely in all patients. All patients engaged in research were informed and gave voluntary written consent to medical manipulations. The design of research was approved by the ethic committee of the Faculty of Medicine, Petrozavodsk State University. Statistical analysis was conducted using Statistics 6 software. The p-value $=0.05$ was considered statistically significant according to Student t-test, Mann-Whitney U-test, $\chi^{2}$-test.

\section{Results}

We have examined 83 patients with CHC: 49 (59.0\%) were males, 34 (41.0\%) were females; the mean age was $39.3 \pm 12.3$ (range: 17 - 72) years. Chronic hepatitis was diagnosed in 74 (89.2\%) patients, and cirrhosis - in $9(10.8 \%)$ patients. Genotype $1 \mathrm{HCV}$ was determined in 42 (50.6\%) patients, among them subgenotype $1 \mathrm{~b}$ was revealed in 36 (43.4\%) patients and subgenotype $1 \mathrm{a}$ - in $6(7.2 \%)$ patients. Patients with subgenotype $1 \mathrm{~b}$ and $1 \mathrm{a}$ were combined into one group. Genotype 1 group included 24 males $(57.1 \%)$ and $18(42.9 \%)$ females (the average age $37.1 \pm 14.6$ years). Genotype $3 \mathrm{a} \mathrm{HCV}$ was determined in $41(49.4 \%)$ patients: males $-25(61.0 \%)$, females $-16(39.0 \%)$ (the average age $41.1 \pm 10.7$ years).

Extrahepatic manifestations were observed twice as often in patients with genotype $1 \mathrm{HCV}$ than in patients bearing HCV 3a genotype : 18 (42.9\%) vs. 9 (21.9\%) patients, respectively) (Table 1). Arthralgia and cryoglobulinemic vasculitis were the most frequent systemic manifestations 
found in patients carrying genotype $1 \mathrm{HCV}$. Arthralgia was observed in $5(25.3 \%)$ patients, and a complex of polyorganic lesions (cutaneous vasculitis, glomerulonephritis and arthralgia) was detected with the same frequency - in $5(25.3 \%)$ patients with genotype $1 \mathrm{HCV}$. Arthralgia was localized mainly in large joints of upper and lower extremities and was not accompanied by clinical or roentgenologic signs of inflammation or structural alterations. Our data are in accordance with the results of other authors reporting on arthralgia as the most frequent extrahepatic manifestation in CHC (Ferri, 2004; Ali, 2005; Galossi, 2007; Krel, 2009; Baǐkova, 2013).

Simultaneous symptoms of cutaneous vasculitis, glomerulonephritis and arthralgia were observed in 5 patients. Cutaneous vasculitis developed as purpura in lower legs in 4 patients, and in legs and buttocks in 1 patient. Glomerulonephritis manifested itself in the form of proteinuria and hematuria in 4 patients, and in the form of proteinuria, hematuria and hyperkreatininemia (130-250 mkmol/l) - in 1 patient. Arterial hypertension and nephrotic syndrome were not observed. Mixed cryoglobulinemia was detected in all 5 patients. According to many authors, membranoproliferative glomerulonephritis is a typical renal manifestation in $\mathrm{CHC}$ and is characterized by mild course in more than $50 \%$ of cases despite that glomerulonephritis per se is a negative prognostic factor (Daghestani, 1999; Ferri, 2004).

Isolated purpura without glomerulonephritis symptoms was observed in $2(10.5 \%)$ females displayed positive result in a mixed cryoglobulinemic test.

Raynaud's phenomenon was observed in $1(2.4 \%)$ 35-year man with cryoglobulinemia, and was characterized by progressive course and development of necrosis of distal phalanges of a few fingers. For this patient, $\mathrm{CHC}$ had subclinical course with minimal alterations in laboratory tests doubly elevated ALT and AST (alanine / aspartate aminotransferase) levels. As it follows from literature data, Raynaud's phenomenon is detected in $30 \%$ of cases in cryoglobulinemia and develops more frequently in females than in males (Ferri, 2004), although its occurrence in CHC is not sufficiently studied.

Type 2 diabetes mellitus was detected in 1 female with genotype 1 infection. According to literature data, diabetes is a CHC-associated disease, but its pathogenesis is not yet well defined. Knobler et al. have shown that insulinoresistance and deterioration of B-cell functions occur in CHC patients due to TNF $\alpha$ effect (Knobler, 2005). Several researchers observed diabetes mellitus more frequently in patients with genotype 2a HCV (Mason, 1999) and advanced liver fibrosis (Papatheodoridis, 2006). At the same time, some authors have found that patients with diabetes mellitus are more susceptible to infection by hepatitis C virus (Guo, 2013). Other researchers suppose that HCV serves as a trigger in the development of type 1 diabetes in susceptible persons. In our case, type 1 diabetes was not detected among the examined $\mathrm{CHC}$ patients.

Autoimmune thyroiditis was diagnosed in $3(15.8 \%)$ CHC patients carrying HCV subtype 1. Its occult course was proved by thyroid ultrasonography and laboratory tests including thyroid hormones and anti-thyroglobulin autoantibodies. According to epidemiological data, autoimmune thyroiditis is a CHC-associated disease, however, additional evidence of its close etiological and pathogenic connection with chronic HCV-infection is still required (Khattab, 2010).

Table 1. The frequency of extrahepatic manifestations observed in CHC patients with different HCV genotypes

\begin{tabular}{cccc}
\hline Signs & $\begin{array}{c}\text { Genotype } 1 \\
\text { HCV }\end{array}$ & $\begin{array}{c}\text { Genotype 3a } \\
\text { HCV }\end{array}$ & Total \\
\hline Total number of patients, n (\%) & $42(50.6 \%)$ & $41(49.4 \%)$ & 83 \\
\hline $\begin{array}{c}\text { Patients with extrahepatic } \\
\text { manifestations, n (\%) }\end{array}$ & $18(42.9 \%)$ & $9(22,0 \%) *$ & $27(32.5 \%)$ \\
\hline Arthralgia, n (\%) & $5(16.7 \%)$ & $2(4.9 \%)^{*}$ & $7(8.4 \%)$
\end{tabular}




\begin{tabular}{cccc}
$\begin{array}{c}\text { Purpura, glomerulonephritis, } \\
\text { arthralgia, } \mathrm{n}(\%)\end{array}$ & $5(9.5 \%)$ & $0 \% *$ & $5(6.0 \%)$ \\
\hline Purpura, $\mathrm{n}(\%)$ & $2(4.8)$ & $0 \% *$ & $2(2.4 \%)$ \\
\hline Thyroiditis, $\mathrm{n}(\%)$ & $3(7.1 \%)$ & $3(7.5 \%)$ & $6(7.2 \%)$ \\
\hline Type 2 diabetes mellitus, $\mathrm{n}(\%)$ & $1(2.4 \%)$ & $2(5.0 \%)$ & $3(3.6 \%)$ \\
\hline Non-Hodgkin Iymphoma, $\mathrm{n}(\%)$ & $1(2.4 \%)$ & & $1(1.2 \%)$ \\
\hline Raynoud's phenomenon, $\mathrm{n}(\%)$ & $1(2.4 \%)$ & - & $1(1.2 \%)$ \\
\hline Vitiligo, $\mathrm{n}(\%)$ & $0 \%$ & $1(2.4 \%)$ & $1(1.2 \%)$ \\
\hline Psoriasis, $\mathrm{n}(\%)$ & $0 \%$ & $1(2.4 \%)$ & $1(1.2 \%)$ \\
\hline *- p<0.05 & & &
\end{tabular}

Non-Hodgkin lymphoma was diagnosed in a 56-year male by means of biopsy of enlarged neck lymph nodes and bone marrow. CHC revealed by ELISA and PCR was characterized by mild activity according to clinical and laboratory data. Non-Hodgkin lymphoma as well as diabetes belongs to $\mathrm{CHC}$-associated diseases. The risk of its occurrence increases by $20-30 \%$ in $\mathrm{CHC}$ patients as compared with common population (Giordano, 2007), but pathogenesis of neoplasm development is still unclear. The ability of HCV to infect B-cells could be explained by tropism of viral envelop protein E2 to CD81 receptors on the surface of B-cells. As a result of infection, Bcells become activated and start to produce polyclonal and monoclonal cryoglobulins. Furthermore, in infected B-lymphocytes apoptotic pathway is destroyed and expression of oncogenic proteins is increased leading to lymphoma development. In addition to other infections, various environmental and genetic factors can induce neoplastic transformation of B-cells (Nicolau, 2011).

Five patients with purpura plus glomerulonephritis, who displayed the highest level of hepatocellular inflammation and fibrosis, were the oldest in the group and had the largest disease duration. Four of them (80.0\%) had liver cirrhosis (Table 2).

Table 2. Clinical, laboratory and histological parameters for patients with HCV type 1 infection and various extrahepatic manifestations $(\mathrm{M} \pm \mathrm{m})$

\begin{tabular}{|c|c|c|c|c|c|c|c|c|}
\hline Signs & $\begin{array}{c}\text { Arthral- } \\
\text { gia }\end{array}$ & 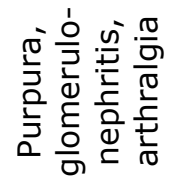 & Purpura & $\begin{array}{l}\text { Thyro- } \\
\text { iditis }\end{array}$ & $\begin{array}{c}\text { Type 2 } \\
\text { Diabe- } \\
\text { tes }\end{array}$ & $\begin{array}{l}\text { Non- } \\
\text { Hodgkin } \\
\text { Lym- } \\
\text { phoma }\end{array}$ & $\begin{array}{l}\text { Ray- } \\
\text { noud's } \\
\text { pheno- } \\
\text { menon }\end{array}$ & Total \\
\hline $\begin{array}{c}\text { Number of } \\
\text { patients, } \\
n(\%)\end{array}$ & $\begin{array}{c}5 \\
(25.3 \%)\end{array}$ & $\begin{array}{c}5 \\
(26.3 \%)\end{array}$ & $\begin{array}{c}2 \\
(10.5 \%)\end{array}$ & $\begin{array}{c}3 \\
(15.8 \%)\end{array}$ & $\begin{array}{c}1 \\
(5.3 \%)\end{array}$ & $\begin{array}{c}1 \\
(5.3 \%)\end{array}$ & $\begin{array}{c}1 \\
(5.3 \%)\end{array}$ & 18 \\
\hline $\begin{array}{l}\text { Males, } \\
\mathrm{n}(\%)\end{array}$ & $\begin{array}{c}2 \\
(40.0 \%) \\
\end{array}$ & 0 & 0 & 1 & 0 & 1 & 1 & $\begin{array}{c}5 \\
(27.8 \%) \\
\end{array}$ \\
\hline $\begin{array}{c}\text { Females, } \\
\mathrm{n}(\%)\end{array}$ & $\begin{array}{c}3 \\
(60.0 \%) \\
\end{array}$ & 5 & 2 & 2 & 1 & 0 & 0 & $\begin{array}{c}13 \\
(72.2 \%) \\
\end{array}$ \\
\hline $\begin{array}{l}\text { Age, } \\
\text { years }\end{array}$ & $\begin{array}{c}57.02 \pm \\
4.8 \\
\end{array}$ & $\begin{array}{c}55.5 \pm \\
5.5 \\
\end{array}$ & $\begin{array}{c}37.6 \pm \\
14.8 \\
\end{array}$ & $\begin{array}{c}39.0 \pm \\
10.9 \\
\end{array}$ & 39.0 & 51.0 & 35.0 & $\begin{array}{c}48.7 \pm \\
11.0 \\
\end{array}$ \\
\hline $\begin{array}{c}\text { Disease } \\
\text { duration, } \\
\text { years }\end{array}$ & $\begin{array}{c}19.5 \pm \\
7.2\end{array}$ & $\begin{array}{c}19.7 \pm \\
9.6\end{array}$ & $\begin{array}{c}10.0 \pm \\
7.2\end{array}$ & $5.7 \pm 3.0$ & 10 & 9 & 7 & $\begin{array}{c}11.8 \pm \\
8.6\end{array}$ \\
\hline $\begin{array}{c}\text { Hepatitis, } \\
\text { n (\%) }\end{array}$ & $\begin{array}{c}2 \\
(40.0 \%)\end{array}$ & 1 & 2 & 2 & 1 & 1 & 1 & $\begin{array}{c}10 \\
(55.6 \%)\end{array}$ \\
\hline $\begin{array}{c}\text { Cirrhosis, } \\
\text { n (\%) }\end{array}$ & $\begin{array}{c}3 \\
(60.0 \%)\end{array}$ & 4 & 0 & 1 & 0 & 0 & 0 & $\begin{array}{c}8 \\
(44.4 \%)\end{array}$ \\
\hline
\end{tabular}




\begin{tabular}{|c|c|c|c|c|c|c|c|c|}
\hline$A L T, U / I$ & $\begin{array}{c}109.1 \pm \\
35.4\end{array}$ & $\begin{array}{c}146.3 \pm \\
41.3\end{array}$ & $\begin{array}{c}64.9 \pm \\
29.5 \\
\end{array}$ & $\begin{array}{c}74.9 \pm \\
29.6 \\
\end{array}$ & 70.8 & 100.3 & 76.7 & $\begin{array}{c}92.6 \pm \\
41.3\end{array}$ \\
\hline AST, U/I & $\begin{array}{c}79.7 \pm \\
23.6\end{array}$ & $\begin{array}{c}92.6 \pm \\
17.7\end{array}$ & $\begin{array}{c}53.1 \pm \\
19.3 \\
\end{array}$ & $\begin{array}{c}60.77 \pm \\
20.4 \\
\end{array}$ & 53.6 & 95.5 & 60.3 & $\begin{array}{c}71.02 \pm \\
21.0\end{array}$ \\
\hline $\begin{array}{l}\text { Bilirubin, } \\
\text { mkmol// }\end{array}$ & $\begin{array}{c}16.3 \pm \\
2.7 \\
\end{array}$ & $\begin{array}{c}16.8 \pm \\
1.9 \\
\end{array}$ & $\begin{array}{c}15.2 \pm \\
1.3 \\
\end{array}$ & $\begin{array}{c}20.9 \pm \\
4.1 \\
\end{array}$ & 14.5 & 13.6 & 16.8 & $\begin{array}{c}17.1 \pm \\
6.2 \\
\end{array}$ \\
\hline HAI, score & $8.6 \pm 4.1$ & $\begin{array}{c}14.1 \pm \\
2.3\end{array}$ & $\begin{array}{c}12.5 \pm \\
3.5\end{array}$ & $\begin{array}{c}11.0 \pm \\
6.5\end{array}$ & 5 & - & - & $\begin{array}{c}12.6 \pm \\
4.7\end{array}$ \\
\hline $\mathrm{F}$, score & $2.4 \pm 1.5$ & $3.5 \pm 0.4$ & $2.0 \pm 1.4$ & $2.3 \pm 1.5$ & 1 & - & - & $3.0 \pm 1.2$ \\
\hline
\end{tabular}

Liver cirrhosis was also diagnosed in $3(60.0 \%)$ of 5 patients with arthralgia. These patients did not show high level of serum ALT and histological activity compared to patients with combined purpura and glomerulonephritis. Cryoglobulinemia was detected in 8 (19.0\%) patients bearing genotype $1 \mathrm{HCV}$ and developing purpura, glomerulonephritis and Raynaud's phenomenon.

Within the group of genotype $1 \mathrm{HCV}$ infected patients, extrahepatic manifestations were found more often in females $(13-72.2 \%)$ than in males $(5-27.8 \%, \mathrm{p}<0.05)$. Some authors also report on gender dependence of certain systemic manifestations of $\mathrm{CHC}$, with more frequent occurrence in females, than in males (Stefanova-Petrova, 2007). At the same time, it is accepted that the risk of $\mathrm{CHC}$ is higher in men than in women.

The frequency of EHM in patients with genotype 3a virus was $22.2 \%$, which is 2 times less than for patients with genotype 1 virus. Thyroiditis was revealed in $3(33.3 \%)$ patients (Table 3$)$. It had subclinical course as diagnosed by ultrasonography of thyroid gland and elevated levels of thyroid hormones. Arthralgia and type 2 diabetes were observed in equal number of patients $(22.2 \%)$. Vitiligo was defined in $1(11.1 \%)$ patient as well as psoriasis.

Liver cirrhosis was not diagnosed in patients with HCV of $3 a$ genotype. Clinical and laboratory activity of CHC did not differ from that observed in patients with HCV genotype 1, however, histological activity index and fibrosis in patients with HCV $3 \mathrm{a}$ were significantly lower than those in patients with HCV type $1(\mathrm{p}<0.05)$.

Cryoglobulines were identified only in 1 (11.1\%) HCV3a-positive CHC-patient with arthralgia versus $8(19.0 \%)$ patients with HCV type 1 infection. Other authors report on the higher frequency of cryoglobulinemia development in HCV2a/c-positive patients (Franguel, 1996).

Within the group of HCV3a-infected patients, systemic manifestations of HCV-infection were observed more often in females $(7-77.7 \%)$ than in males $(2-22.2 \%)$ which is similar to the group of $\mathrm{HCV}$ type 1 positive patients.

Table 3. Clinical, laboratory and histological parameters for patients with HCV type 1 infection and various extrahepatic manifestations $(\mathrm{M} \pm \mathrm{m})$

\begin{tabular}{ccccccc}
\hline Signs & Arthralgia & $\begin{array}{c}\text { Thyroi- } \\
\text { ditis }\end{array}$ & $\begin{array}{c}\text { Type } 2 \\
\text { Diabetes } \\
\text { mellitus }\end{array}$ & Vitiligo & Psoriasis & Total \\
\hline $\begin{array}{c}\text { Number } \\
\text { of patients, } \\
\mathrm{n}(\%)\end{array}$ & $2(22.2 \%)$ & $3(33.3 \%)$ & $2(22.2 \%)$ & $1(11.1 \%)$ & $1(11.1 \%)$ & 9 \\
\hline Males, $\mathrm{n}(\%)$ & 0 & 0 & $1(11.1 \%)$ & 0 & $1(11.1 \%)$ & $2(22.2 \%)$ \\
\hline Females, n (\%) & $2(22.2 \%)$ & $3(33.3 \%)$ & $1(11.1 \%)$ & $1(11.1 \%)$ & 0 & $7(77.8 \%)$ \\
\hline $\begin{array}{c}\text { Age, years } \\
\text { Disease } \\
\text { duration, years }\end{array}$ & $11.5 \pm 4.6$ & $6.0 \pm 5.6$ & $6.0 \pm 1.4$ & 10 & 4 & $6.7 \pm 7.2$ \\
\hline $\begin{array}{c}\text { Hepatitis, } \\
\mathrm{n}(\%)\end{array}$ & $2(22.2 \%)$ & $3(33.3 \%)$ & $2(22.2 \%)$ & $1(11.1 \%)$ & $1(11.1 \%)$ & $9(100 \%)$ \\
\hline $\begin{array}{c}\text { Liver cirrhosis, } \\
\mathrm{n}(\%)\end{array}$ & 0 & 0 & 0 & 0 & 0 & 0
\end{tabular}




\begin{tabular}{ccccccc} 
ALT, U/I & $97.9 \pm 53.4$ & $56.1 \pm 39.5$ & $186.5 \pm 52.3$ & 221.7 & 142.4 & $132.6 \pm 56.3$ \\
\hline AST, U/I & $73.1 \pm 26.1$ & $24.4 \pm 8.1$ & $71.9 \pm 9.4$ & 80.3 & 74.1 & $49.1 \pm 14.3$ \\
\hline $\begin{array}{r}\text { Bilirubin, } \\
\text { mkmol/I }\end{array}$ & $17.2 \pm 5.3$ & $23.1 \pm 21.0$ & $13.5 \pm 0.9$ & 15.6 & 16.3 & $17.5 \pm 10.2$ \\
\hline HAI, score & $7.2 \pm 0.8$ & $7.5 \pm 0.7$ & $11.5 \pm 2.1$ & 6 & 5 & $8.0 \pm 3.0$ \\
\hline F, score & $1.0 \pm 0.0$ & $1.0 \pm 0.0$ & $1.0 \pm 0.0$ & 1 & 1 & $1.1 \pm 0.0$ \\
\hline
\end{tabular}

\section{Conclusions}

1. Extrahepatic manifestations were detected in $32.5 \%$ of patients with chronic hepatitis $\mathrm{C}$ and characterized by high frequency of arthralgia, purpura and glomerulonephritis caused by cryoglobulinemia.

2. Extrahepatic manifestations occurrence depends both on viral and host factors.

3. HCV genotype, comparing to other viral factors, significantly affected the frequency of extrahepatic manifestations in CHC-patients: EHM occurred twice as often in group of HCV type 1 positive persons than in group of HCV 3a positive.

4. As for the host factors, it was gender that significantly influenced the frequency of extrahepatic manifestations in CHC: EHM occurred 3 times more frequently in females than in males.

\section{References}

1. Ali A, Zein NN. Hepatitis C infection: A systemic disease with extrahepatic manifestations. Cleveland Clinic J of Medicine 2005, 72:1005-1019.

2. Baikova TA, Lopatkina TN. A variety of extrahepatic manifestations of chronic viral hepatitis B and C: basic treatment principles. Ter Arkh 2013, 85(4):100-110.

3. Daghestani L, Pomeroy C. Renal manifestations of hepatitis C Infection. Am J Med 1999, 106:347-354.

4. Ferri C, Sebastiani M, Giuggioli D, Cazzato M, Longombardo G, Antonelli A, Puccini R, Michelassi C, Zignego AL. Mixed cryoglobulinemia: demographic, clinical, and serological features and survival in 231 patients. Semin Arthritis Rheum 2004, 33:355-374.

5. Franguel L, Musset L, Cresta P, Cacoub P, Huraux JM, Lunel F. Hepatitis C virus genotypes and subtypes in patients with hepatitis $\mathrm{C}$, with and without cryoglobulinemia. J Hepatol 1996, 25:427-432.

6. Galossi A, GuariscoR, Bellis L, Puoti C. Extrahepatic Manifestations of Chronic HCV Infection. J Gastrointestin Liver Dis 2007, 16(1):65-73.

7. Giordano TP, Henderson L, Landgren O, Chiao EY, Kramer JR, El-Serag H, Engels EA. Risk of non-Hodgkin lymphoma and lymphoproliferative precursor diseases in US veterans with hepatitis C virus. JAMA 2007, 297(18):2010-2017.

8. Guo X, Jin M, Yang M et al. Type 2 Diabetes Mellitus and the Risk of Hepatitis C Virus Infection: A systematic Review. Scientific reports 2013, 3:2981 -2988.

9. Kallemuchikkal U, Gorevic PD. Evaluation of Cryoglobulins. Arch Pathol Lab Med 1999, 123:119-125.

10. Khattab MA, Eslam M, Alavian SM. Hepatitis C Virus as a Multifaceted Disease: A Simple and Updated Approach for Extrahepatic Manifestations of Hepatitis C Virus Infection. Hepat Mon 2010, 10(4):258-269.

11. Knobler H, Schattner A. TNF- $\alpha$, chronic hepatitis $\mathrm{C}$ and diabetes: a novel triad. QJM 2005, 98:1-6.

12. Krel' PE, Tsinzerling OD. The extrahepatic site of hepatitis $\mathrm{C}$ virus: clinical manifestations and prognostic value. Ter Arkh 2009, 81(11):63-68. 
13. Mason AL, Lau JY, Hoang N, Qian K, Alexander GJ, Xu L, Guo L, Jacob S, Regenstein FG, Zimmerman R, Everhart JE, Wasserfall C, Maclaren NK, Perrillo RP. Association of diabetes mellitus and chronic hepatitis C virus infection. Hepatology 1999, 29(2):328-333.

14. Nicolau A, Tănăsescu R, Bălănescu E, Bălănescu P, Pătraşcu R, Tănăsescu C. Hepatitis C virus-mixed cryoglobulinemia-lymphoma relationship. Rom J Intern Med 2011, 49(1):3-10.

15. Papatheodoridis GV, Chrysanthos N, Savvas S, Sevastianos V, Kafiri G, Petraki K, Manesis EK. Diabetes mellitus in chronic hepatitis B and C: prevalence and potential association with the extent of liver fibrosis. J Viral Hepat 2006, 13(5):303-310.

16. Stefanova-Petrova DV, Tzvetanska AH, Naumova EJ, Mihailova AP, Hadjiev EA, Dikova RP, Vukov MI, Tchernev KG. Chronic hepatitis $\mathrm{C}$ virus infection: prevalence of extrahepatic manifestations and association with cryoglobulinemia in Bulgarian patients. World $J$ Gastroenterol 2007, 13(48):6518-6528. 